\title{
PERLINDUNGAN HUKUM TERHADAP SAKSI
}

\author{
Ahkam Jayadi \\ Universitas Islam Negeri Alauddin Makassar \\ ahkamjayadi@gmail.com
}

\begin{abstract}
The presence of a witness in giving testimony in the realm of crime has a very important position because he is one of the evidences that will prove whether or not someone has committed a crime. Thus the witness must obtain legal protection as appropriate. Most of the people still don't understand and don't want to be witnesses or testify against the occurrence of a criminal act because being a witness is very problematic because if one witnesses it can turn into a suspect. This is further exacerbated by the persistence of people's poor perception of law enforcement officers (police, prosecutors and judges) so that they are afraid to be witnesses and give testimony.
\end{abstract}

Keywords: Criminal, Protection, Testimony.

\begin{abstract}
Abstrak
Kehadiran seorang saksi dalam memberikan kesaksian dalam ranah tindak pidana mempunyai kedudukan yang sangat penting oleh karena dialah salah satu alat bukti yang akan membuktikan benar tidaknya seseorang telah melakukan tindak pidana. Dengan demikian saksi harus mendapatkan perlindungan hukum sebagaimana mestinya. Sebagian besar masyarakat masih banyak yang tidak memahami dan tidak mau menjadi saksi atau bersaksi terhadap terjadinya sebuah tindak pidana karena menjadi saksi itu sangat problematik sebab bila salah bersaksi maka justru bisa berbalik menjadi tersangka. Hal tersebut semakin diperparah dengan masih adanya persepsi masyarakat yang buruk terhadap aparat penegak hukum (polisi, jaksa dan hakim) sehingga takut menjadi saksi dan memberikan kesaksian.
\end{abstract}

\section{Kata Kunci : Kesaksian, Perlindungan, Pidana.}

\section{PENDAHULUAN}

Upaya mendukung penegakan hukum, maka perlindungan terhadap saksi kini dilakukan oleh sebuah lembaga khusus yang disebut, "Lembaga Perlindungan Saksi dan Korban". Sebenarnya apa yang menjadi tugas dan fungsi Lembaga Perlindungan Saksi dan Korban (LPSK) bukanlah hal baru. Tugas dan fungsi perlindungan saksi dan korban telah ada pada Kepolisian (sebagai penyidik), Jaksa sebagai penuntut umum serta Hakim. Bukankah institusi-institusi hukum tersebut fungsinya adalah memberikan rasa aman dan keadilan kepada 
masyarakat ${ }^{1}$. Memberikan perlindungan yang sama dan perlakuan yang sama dalam hukum (equal protection and equal treatment of the law) termasuk perlindungan hukum terhadap saksi tidak hanya fisiknya akan tetapi dalam persaksiannya. Dengan demikian kita jangan membutuhkan seorang saksi hanya berkaitan dengan kesaksiaannya akan tetapi mengabaikan keselamatan pribadinya bahkan termasuk keluarganya ${ }^{2}$.

Mungkin pada aspek normatif hal itu memang tidak diatur secara khusus dan jelas akan tetapi aturan yang secara umum dapat dijadikan dasar telah ada pada Kitab Undang Undang Hukum Acara Pidana (KUHAP) seperti Pasal 108 tentang hak dan kewajiban saksi atau korban untuk melaporkan atau mengadukan ke penyelidik atas terjadinya sebuah tindak pidana. Serta Pasal 116 tentang pemeriksaan saksi dan selama ini hal itu telah terlaksana ${ }^{3}$. Untuk itu yang diperlukan sebenarnya adalah kreativitas serta inovasi dari aparat penegak hukum yang ada (diskresi power). Hanya sayangnya kebanyakan aparat penegak hukum kita hingga saat ini selalu terikat secara kaku pada aturan normatif yang ada, karena menganut pemikiran-pemikiran sistem hukum Eropa Kontinental yang normatif-positivistik atau legalistik formal ${ }^{4}$ yang di anut negara kita. Prosesproses penyelidikan, penyidikan bahkan pemeriksaan di pengadilan terlihat sangat kaku dan kering dari nilai-nilai kemanusiaan.

Untuk itu kehadiran LPSK untuk menjamin perlindungan saksi dan korban dalam kaitan terjadinya suatu tindak pidana tentu saja diharapkan akan semakin meningkatkan penghargaan dan perlindungan terhadap saksi. Selama ini penyelesaian suatu tindak pidana tidak maksimal, oleh karena terkendala pada kehadiran saksi (kunci) untuk memberikan kesaksian guna memperoleh kebenaran materiil ${ }^{5}$. Hanya saja dalam realitas hal itu tidak terwujud secara baik oleh karena saksi telah diintimidasi sebelumnya agar tidak memberikan kesaksian. Terkadang nyawa taruhannya, atau sebaliknya saksi dan korban telah dibayar oleh pelaku

1 Yahya Harahap, Pembahasan Permasalahan dan Penerapan KUHAP, Jakarta: Sinar Grafika, 2007.

${ }^{2}$ Kerelaan seseorang menjadi saksi sebuah tindak pidana adalah refleksi warga Negara yang baik untuk mendukung penegakan hukum. Menjadi saksi tidak dibayar, bahkan salah sedikit dalam bersaksi bisa menjadi tersangka oleh sebab itu Negara melalui Pemerintah (LPSK) harus benar-benar menghargai serta menghormati sikap tersebut dan berusaha semaksimal mungkin melakukan perlindungan sebagai balasannya.

${ }^{3}$ Soenarto Soedibroto, KUHP dan KUHAP Dilengkapi Yurisprudensi Mahkamah Agung dan Hoge Raad, Jakarta: PT. Raja Grafindo Persada, 2006.

${ }^{4}$ Otje Salman dan Anthon F. Susanto, Teori Hukum, Mengingat, Menyimpulkan, dan Membuka Kembali, PT. Refika Aditama, Bandung, 2009.

${ }^{5}$ Arief, Barda Nawawi, Masalah Penegakan Hukum dan Kebijakan Hukum Pidana Dalam Penanggulangan Kejahatan, Jakarta: Kencana Prenada Media Group, 2007.

131 
sehingga kesaksiannya untuk menguntungkan pelaku sebagaimana telah disepakati ${ }^{6}$.

Kesaksian korban atau saksi untuk mengungkap kebenaran suatu tindak kejahatan sangat diperlukan seiring dengan masih tingginya angka kejahatan di negara kita. Bukankah betapa memilukan bila kita membaca data sebahagian kejahatan (tindak pidana). sebagai berikut: Laporan BPK 1999-2004, penyelewengan uang negara terjadi Rp 166,5 triliun, yang Rp 144 triliun adalah pelanggaran BLBI, dan yang terakhir adalah korupsi yang dilakukan oleh Anggota DPR periode 2004-2009 mulai dari pemilihan Gubernur Bank Indonesia, Pembangunan Bagan Siapi-api, pengembangan Bandara di Indonesia Timur serta kasus Bank Century. Data ICW kerugia Negara akibat korupsi tahun 2013 mencapai 6,011 trilyun, pada tahun 2014 mencapai 7,163 trilyun dan pada tahun 2015 mencapai 3,107 trilyun ${ }^{7}$. Korupsi yang paling banyak adalah anggota legislatif, yakni 37 persen, disusul pejabat dinas pemda 18 persen, eksekutif 15 persen, pimpro 10 persen, parpol 3 persen, dan kepolisian 2 persen. Temuan KPK tersebut tak jauh berbeda dengan yang dirilis Mendagri, yang menyebut ada sekitar 1.110 pejabat daerah korup. Pejabat daerah tersebut meliputi 7 gubernur, 60 bupati/wali kota, 327 anggota DPRD provinsi dan 735 anggota DPRD di berbagai kabupaten dan kota yang tersebar di seluruh wilayah Indonesia ${ }^{8}$. Dan yang terakhir adalah skandal mega koropsi dalam penangan E-KTP yang mencapai 2,7 Trilyun yang melibatkan elit-elit politik dan elit-elit pemerintahan hingga menggemparkan di awal tahun 2017 ini. Bahkan salah satu pelakunya yang sekaligus Ketua DPR RI kini dalam tahanan KPK.

Demikian juga dengan berbagai kasus perampokan, pembunuhan dan pemerkosaan. Bahkan yang menghebohkan masyarakat kita beberapa bulan terakhir adalah pemerkosaan dan pembunuhan yang dilakukan oleh dan terhadap anak-anak dibawah umur. Bahkan sakin seriusnya hal tersebut pemerintah sampai mengeluarkan peraturan pemerintah pengganti undang-undang (Perpu No. 1 Tahun 2016) dan menambahkan hukum kebiri kepada pelakunya. Termasuk berbagai pembunuhan sadis yang korbannya di cincang atau di mutilasi. Benarbenar kelakuan sadis yang selama ini hanya dilakukan oleh binatang buas yang ada di hutang. Mungkinkah ini pembuktian akan kebenaran ayat Alqur'an bahwa manusia bisa lebih hina dari binatang.

\footnotetext{
${ }^{6}$ Sholehuddin, Sistem Sanksi Dalam Hukum Pidana Ide Dasar Double Track System dan Implementasinya, Jakarta: PT. Raja Grafindo Persada, 2004.

${ }^{7}$ Laporan ICW di upload dari Republik.co.id, Rabu 24 Februari 2016.

${ }^{8}$ Lihat lebih lanjut laporan berkala KPK setiap Tahun.
} 
Kebanyakan kasus-kasus tersebut tidak dapat terselesaikan dengan baik oleh karena saksi atau korban tidak dapat berperan secara maksimal. Dalam kaitan ini LPSK kehadirannya menjadi sebuah keniscayaan dalam menjamin keberadaan saksi dan korban untuk mengungkap sebuah kejahatan dalam arti bahwa kehadirannya adalah untuk mengejawantahkan secara lebih maksimal dan massif peran tersebut yang sebelumnya telah ada pada lembaga-lembaga penegak hukum yang ada sebagaimana disebutkan di atas. Dalam upaya mewujudkan peran tersebut tentu saja perlu dikaji terlebih dahulu hal-hal berikut: Bagaimana UU No. 13 tahun 2006 mengatur tentang perlindungan saksi. Apakah problematika yang melingkupi keberadaan saksi dengan kesaksiannya. Format pembahasan makalah ini menggunakan teori "Efektivitas Hukum" yang menelusuri hukum dalam substansinya dan dalam realitasnya.

\section{METODE PENELITIAN}

Penelitian ini dilakukan berdasarkan studi pustaka dengan berbagai referensi jurnal dan buku serta beberapa artikel terbaik dan terupdate. Penelitian Pustaka (library research) yaitu Penelitian dilaksanakan dengan mengumpulkan data dan landasan teoritis dengan mempelajari buku, karya ilmiah, hasil penelitian terdahulu, jurnal-jurnal terkait, artikel-artikel yang terkait serta sumber-sumber yang terkait dengan penelitian sesuai dengan penelitian yang diteliti. Setelah semua data telah diperoleh berhasil dikumpulkan selama proses penelitian baik data primer dan data sekunder dianalisis secara kualitatif kemudian disajikan secara deskriptif yaitu menjelaskan, menguraikan, menggambarakan permasalahan yang berkaitan dengan pelindungan hukum terhadap saksi.

\section{PEMBAHASAN}

\section{A. Urgensi Perlindungan Saksi}

Bila kita analisis aspek normatif Undang Undang No. 13 Tahun 2006, secara umum telah mengatur secara memadai adanya perlindungan kepada saksi dan korban dari suatu tindak pidana. Meskipun bila kita analisis pasal-pasalnya, maka ada beberapa pasal yang secara khusus bagi penulis dapat menimbulkan masalah. Beberapa pasal tersebut adalah Pasal 5 dan Pasal 8, yang menempatkan kesaksian itu sebagai hak. Sebagai hak tentu saja saksi dan korban dapat menggunakan atau tidak menggunakan haknya tersebut. Padahal seharusnya menjadi kewajiban dari saksi dan korban serta kewajiban dari negara untuk saling membantu dalam penanganan sebuah tindak pidana termasuk memberikan perlindungan kepada saksi agar dapat memberikan kesaksiaanya tanpa rasa takut termasuk yang berkaitan dengan keselamatan atas dirinya dan keluarganya akibat kesaksian yang 
diberikannya. Jadi seharusnya pasal tersebut bukan menempatkan pemberian kesaksian itu sebagai hak akan tetapi sebagai kewajiban sebagai warga Negara yang baik, karena kesaksiaannya turut membantu upaya penegakan hukum.

Pasal 2, yang terlalu membatasi pemberian perlindungan pada saksi dan korban hanya dalam semua tahap proses peradilan pidana. Seharusnya perlindungan diberikan sejak terjadinya tindak pidana sampai pasca proses persidangan (vonnis) yang tentu saja disesuaikan dengan kondisi perlindungan yang harus diberikan kepada saksi baik terhadap dirinya maupun terhadap keluarganya dan kerabatnya. Jadi perlindungan terhadap saksi harus diberikan secara menyeluruh tidak hanya ketika memberikan kesaksian akan tetapi perlindungan terhadap dirinya dan keluarganya 24 jam setiap hari sampai si saksi merasa aman dan tidak diperlukan lagi perlindungan.

Pasal 4, yang membatasi tujuan pemberian perlindungan (memberikan rasa aman) hanya dalam memberikan keterangan pada setiap proses peradilan pidana. Seharusnya dalam jangkauan yang lebih luas yaitu: dalam hidup kesehariannya (bersama keluarganya). Tentu sebuah kesalahan jika kita hanya butuh dan menghargai kesaksiannya, padahal kesaksian itu keluar dari tubuh fisik si saksi, tidak bisa lahir kesaksiaan kalau si saksi tidak memiliki lagi tubuh yang hidup. Untuk itu perlindungan seharusnya juga di lakukan terhadap fisik si saksi yang tidak hanya untuk dirinya akan tetapi untuk keluarga terdekatnya.

Pasal 8, yang membatasi perlindungan dan hak diberikan sejak tahap penyelidikan. Menurut penulis perlindungan dan hak tersebut harus dimulai sejak terjadinya suatu tindak pidana. Hal ini dimaksudkan agar tercipta kesadaran dari para saksi dan korban untuk senantiasa melaporkan terjadinya suatu tindak pidana atas inisiatifnya sendiri, bukan karena perintah aparat penegak hukum. Hal ini memang masih menjadi masalah hingga sekarang oleh karena masyarakat kita belum memiliki kesadaran untuk menjadi saksi dan bersaksi. Hal ini tentu saja akibat dari ketidak-percayaan masyarakat pada institusi penegakan hukum seperti: kepolisian dan kejaksaan serta pengadilan ${ }^{9}$.

Pasal 14, tentang keanggotaan LPSK yang secara jelas menyebutkan keanggotaanya itu dari: kepolisian, kejaksaan, Kementerian Hukum dan Ham , akademisi, advokat dan LSM, semestinya tidak ada penyebutan seperti itu, oleh karena penulis khawatir penyebutan tersebut akan berimplikasi sebagai bentuk penjatahan. Padahal yang dibutuhkan adalah orang-orang yang memiliki

9 Padahal polisi pelindung dan pengayom masyarakat, sehingga mestinya berurusan dengan polisi adalah hal yang menyenangkan bagi masyarakat akan tetapi kenapa yang terjadi justru sebaliknya, masyarakat takut berurusan dengan kepolisian. 
komitmen moral untuk penegakan hukum dan perlindungan HAM dalam lingkup tugas LPSK. Dengan latar belakang tersebut tentu saja tidak menjadi jaminan bahwa seseorang memiliki integritas moral dan komitmen yang tinggi dalam penegakan hukum (perlindungan saksi dan korban).

Demikian juga dengan Pasal 29 (a) tentang permohonan pemberian perlindungan yang harus dibuat tertulis. Penulis juga khawatir bagaimana dengan masyarakat (saksi dan korban) yang buta huruf atau dalam kondisi yang tidak memungkinkan membuat permohonan tertulis justru akan memperpanjang proses birokrasi dan memungkinkan adanya pihak lain yang memanfaatkan hal ini dan akan menambah keengganan para saksi dan korban untuk memberikan laporan, seharusnya permohonan itu disampaikan secara lisan atau tertulis. Bahkan permohonan tersebut tidak diperlukan bila menurut aparat penegak hukum kepentingan yang bersangkutan menghendakinya sesuai dengan situai dan kondisi yang ada yang melingkupi terjadinya suatu tindak pidana.

Dalam kaitan ini bagi penulis keterlibatan LPSK tidak bisa hanya menerima hasil kerja penyidik (polisi) dan atau penuntut umum (jaksa) yang telah menentukan siapa saksi dan siapa korban dari suatu tindak pidana. Seharusnya anggota atau jajaran LPSK harus juga secara aktif mencari pihak-pihak yang menjadi saksi atau korban suatu tindak pidana (terutama tindak pidana korupsi dan tindak pidana berat lainnya yang mendapat sorotan publik), dengan cara menelusuri secara lebih luas dan dalam suatu tindak pidana yang terjadi. Demikian juga jangan membiasakan hal yang terjadi selama ini dimana suatu tindak pidana yang terjadi termasuk saksi-saksi yang ada telah di ekspos ke publik oleh media sehingga menjadi sorotan publik. Seharusnya pihak kepolisian atau kejaksaan dapat bekerjasama dengan semua media agar tindak pidana tertentu tidak diberitakan ke publik atau kalau pun diberitakan, maka sebaiknya berita itu tidak mengganggu kehadiran saksi atau pihak-pihak yang bisa mengungkap kebenaran suatu tindak pidana yang terjadi akibat pemberitaan yang berlebihan.

Dengan adanya pasal-pasal yang bermasalah tersebut maka secara otomatis implementasi pasal-pasal tersebut akan menghadapi berbagai masalah hukum terutama dalam implementasinya. Untuk itu diperlukan orang-orang yang menjadi anggota LPSK yang memahami betul kondisi UU No. 13 Tahun 2006 dan memiliki kemampuan inovatif dan kreativitas untuk tidak berpegang secara kaku pada rana normatif ${ }^{10}$. Bagaimana pun hukum memang penting akan tetapi hukum tetap hanya alat untuk kemaslahatan manusia dan masyarakat. Hukum sejatinya harus mengabdi untuk kemaslahatan manusia (masyarakat) bukan

10 Harkristuti Harkrisnowo, Pemerintah Harap Terapkan Alternatif Peradilan Anak, Bandung: Refika Aditama, 2003.

135 
sebaliknya manusia mengabdi kepada hukum. Hukum untuk manusi bukan manusia untuk hukum.

\section{B. Pelibatan Aspek Spiritualitas}

Selain pada aspek normatif dan sosio yuridis di atas, maka pendekatan sosio religius juga sebuah keniscayaan ${ }^{11}$. Perlu dipahami dengan baik kondisi saksi dan korban dengan cara mendekati segenap aparat penegak hukum serta saksi dan korban dari sisi aspek hakiki dari diri yang sebenarnya diri. Pada rana inilah sebenarnya yang selama ini banyak tidak dipahami bahwa ketika kita berbicara tentang sosok manusia maka pada hakikatnya manusia tidak akan pernah bisa berprilaku baik dan menjadi baik. Sejak lahir manusia telah membawa sifat-sifat ingkar. Rana inilah yang mendorong manusia senantiasa melakukan tindak kejahatan dengan tidak memperdulikan materi peraturan perundang-undangan yang ada bahkan tata nilai adat istiadat bahkan aturan agama sekalipun. Apalagi bila itu hanya undang-undang buatan manusia.

Pada tataran inilah kita perlu memahami sisi dan proses kejadian manusia (secara universal), karena semua manusia di jagad ini apa pun suku dan bangsanya satu asal kejadiannya, kita jualah yang sering membeda-bedakannya. Semua manusia sama unsur kejadiaannya yang salah satu unsur kejadian tersebut adalah ketika berusia 4 bulan 10 hari di dalam kandungan ibunya, maka ditiupkanlah roh yang lagi-lagi asalnya adalah satu Tuhan yang sama. Inilah sebenarnya wujud nyata semua manusia itu bersaudara. Dengan roh itulah maka manusia memperoleh kehidupan, dapat melihat, dapat mendengar dan dapat berfikir.

Pada rana inilah sosok kejadian manusia dapat di bagi atas: rana fisik (jasmaniah) dan rana roh. Rana jasmaniah juga asal-usulnya sama dari 4 anasir (rahasiaku kata Tuhan) yaitu: anasir angin, air, tanah dan api yang terwujud dalam sari pati tanah dari hasil memakan produk-produk pertanian dan hewan yang memakannya yang kemudian dimakan oleh manusia dan yang mewujud dalam sperma dan sel telur orang tua yang melahirkan. Anasir angin yang memenuhi segala rongga pada jasad membawa sifat-sifat pantang kelintasan. Tidak bisa sembarang mendengar. Jalurnya adalah lewat telingan. Anasir air menjadi urat, benak, tulang pada jasmani dengan membawa sifat-sifat pantang kerendahan. Dengan demikian sifat asli jasmani manusia tidak akan pernah mau dibawa selalu mau di atas. Anasir tanah menjadi daging kulit bulu atau roma pada kita membawa sifat-sifat pantang kurang, tidak ada puasnya. Dan anasir api menjadi

11 Ahkam Jayadi, Memahami Tujuan Penegakan Hukum Sebuah Pendekatan Hikmah, Yogyakarta: Genta Press, 2015.

136 
darah pada kita membawa sifat-sifat pantang kalah. Manusia dengan sifat ini tidak pernah mau kalah meskipun nyata-nyata dia salah. Hal itulah yang membawa sifat-sifat dasar manusia sehingga manusia senantiasa bergejolak dan ingkar kepada TuhanNya.

Sejatinya sifat-sifat jasamaniah ini sengaja Tuhan berikan agar manusia memiliki semangat hidup, akan tetapi harus dikendalikan. Untuk mengendalikannya maka datanglah sifat-sifat ke Tuhanan (di dalam Roh) dengan sifatnya yang siddiq, amanah, tabliq dan fatanah. Inilah sebenarnya sifat-sifat yang harus menguasai hajat hidup kita sehari-hari akan tetapi sayangnya sifat-sifat tersebut terkubur karena dikalahkan oleh sifat-sifat jasmaniah tadi. Hidup keseharian kita hanya diliputi dengan hawa, nafsu dunia yang tiada terkendali. Manusia setiap saat tidak tenang hidupnya yang dikejar hanya memuaskan hawa nafsu duniawi.

Dengan demikian selama manusia belum memahami hakekat dirinya dari sudut pandang agama (spiritualitas) maka selama itu pula kekeliruan dan penghancuran terhadap hidup dan kehidupan ini akan selalu terjadi. Hukum bahkan akan menjadi alat kejahatan (law as tool of crime $)^{12}$. Bahkan melahirkan umat beragama yang bersikap agressif, represif dan anarkhis. Apatah lagi bila manusia yang ada di permukaan bumi ini masih membanggakan kemampuan sains dan teknologi untuk menyelesaikan berbagai persoalan kehidupan manusia. Padahal sains dan teknologi adalah hasil produk berfikir manusia, bagaimana mungkin sains dan teknologi bisa memperbaiki penciptanya.

Dua puluh empat jam sehari kita semua berpikir, sayangnya yang berpikir, yang melihat, yang mendengar dan yang merasa pada dirinya tidak pernah dipahami. Itulah diri yang sebenarnya diri dalam pandangan agama. Sumber asasinya adalah roh yang kemudian nur-Nya memancar di mata, ditelinga, di lidah dan di otak agar bisa berfikir. Dialah yang bila dipanggil yang kuasa maka fisik ini tidak bisa apa-apa lagi. Dialah yang membuat seorang polisi, jaksa dan hakim dapat menangani dan menyelesaikan sebuah masalah hukum. Dialah yang menyebabkan kita dapat memahami apa itu persamaan dan apa itu keadilan. Bagaimana mungkin seorang hakim (sehebat apa pun dianya) dapat memutus sebuah kasus (masalah hukum) di pengadilan bila sang hakim tersebut sudah tidak memiliki roh di dalam tubuhnya, atau yang lebih dikenal dengan telah mati.

Niscaya adanya bahwa pendekatan agama (aspek religius) yang secara sempit oleh Ronald D. Dwarkis, Guru Besar Hukum pada Universitas New York dimaknai dengan "moral" ("Moral Principles is the Foundation of Law") sebagai

${ }^{12}$ Ronny Nitibaskara Rahman, Tegakkan Hukum Gunakan Hukum, Jakarta: Penerbit Buku Kompas, 2007.

137 
sumber nilai-nilai kehidupan yang akan menyelesaikan berbagai persoalan hidup dan kehidupan yang melanda umat manusia di berbagai belahan bumi tentu saja bukan dengan pemaknaan yang umum sebagaimana selama ini kita pahami. Nilainilai agama yang dimaksud tentu saja nilai-nilai agama yang dipahami secara benar sebagaimana telah diajarkan oleh seluruh Nabi-Nabi dan Rasul yang kemudian disusul dengan kehadiran Muhammad Rasulullah SAW. Oleh karena 15 abad setelah kita ditinggal oleh Rasulullah SAW hakekat agama mulai bergeser dengan berbagai tafsiran sesuai dengan kemampuan (akal pikir) para pihak yang menafsirkannya. Akibatnya kita belajar agama dari keterangan ke keterangan sehingga makna dan hakekat agama menjadi hilang. Nilai-nilai ajaran agama menjadi tidak fungsional.

Seringkali kita keliru ketika masalah seperti ini (kejahatan dan berbagai masalah kemasyarakatan yang ada) dipahami dapat diselesaikan melalui penyadaran diri dalam bentuk: introspeksi, refleksi, kontemplasi, yoga, meditasi, iktikaf, tafakur, atau zikir. Apa yang bisa diselesaikan pendekatan seperti ini apabila diri yang sebenarnya diri pada kita tidak dipahami. Tuhan yang disembahNya tidak dikenal dan yang lebih fatal ketika Tuhan di klaim ada di dalam dadanya. Tuhan di pahami ada di urat lehernya. Padahal sebagaimana dikemukakan di atas, ketika kita berusia 4 bulan 10 haris maka Tuhan mengatakan aku tiupkan Roh bukan Tuhan masuk ke dalam tubuh kita. Sayangnya hal itu hingga kini tidak mendapat perhatian secara baik.

Pertanyaannya, kenapa diri yang sebenarnya diri (roh) itu yang esensi dalam diri kita? Karena jasad tak bisa apa-apa jika tidak ada roh. Karena yang beragama, berjalan, berpikir, berbuat, mendengar, merasa, dan yang berbicara melalui pancaindera adalah roh dengan nur-Nya. Pancaindera inilah yabng disebut budi yang melahirkan adat istiadat, sehingga setiap wilayah memiliki adat istiadat yang berbeda. Budi tidak dapat lepas dari kontrol batin yang disebut juga dengan akhlak (moral force) dengan empat sifatnya: siddiq, amanah, tablig, dan fathanah. Sedangkan nyawa adalah perpaduan empat unsur yang membentuk jasad yaitu: angin, air, tanah, dan api yang melahirkan hawa nafsu yang kita kenal juga dengan manusia.

Sayangnya, dalam keseharian keberagamaan masyarakat, hawa nafsu dunia inilah yang memerintah roh kita. Roh menjadi budaknya, padahal yang harus terjadi adalah sebaliknya, roh lah yang harus menjadi panglima. Ini pulahlah yang melahirkan 10 maksiat bathin yaitu: ajib, riya, takabbur, iri, dengki, hasut, fitnah, tamak, lobak dan sombong. Korupsi, membunuh, zinah, pencurian, pornografi dan pornoaksi, terorisme hanyalah implementasi dari 10 maksiat bathin itu dalam bentuk prilaku. Untuk itu selama hal-hal ini tidak dipahami dengan baik maka 
selama itu pula fungsi agama untuk menjadi rahmat bagi diri kita, masyarakat, lingkungan, bangsa dan negara tidak akan pernah dapat terwujud, termasuk di dalam menegakkan tugas untuk menjadi saksi dan memberikan kesaksian. Demikian juga wewenang dan fungsi perlindungan saksi oleh LPSK. Jika tidak, LPSK hanya akan menambah keruhnya persoalan hukum di negara kita. 


\section{PENUTUP}

\section{A. Kesimpulan}

Berdasarkan pembahasan diatas maka, disimpulkan sebagai berikut :

1) Upaya perlindungan terhadap saksi niscaya adanya, oleh karena saksi sangat menentukan pembuktian terjadinya suatu tindak pidana. Hanya saja kesaksian itu tidak mudah dalam implementasinya. Saksi terkadang mendapat teror dari pelaku tindak pidana yang terkadang mengancam jiwanya. Bahkan seringkali saksi dibeli oleh pelaku tindak pidana untuk bersaksi yang menguntungkan pelaku tindak pidana. Dengan dasar ini maka perlindungan saksi menjadi niscaya adanya. Kita bersyukur oleh karena perlindungan terhadap saksi sudah dilembagakan dengan dibentuknya Lembaga Perlindungan Saksi dan Korban.

2) Keberadaan LPSK menjadi niscaya adanya guna menunjang penegakan hukum di Indonesia. Hanya saja LPSK di dalam melaksanakan tugas dan fungsinya, sebaiknya tidak berpegang secara kaku pada undang-undang yang mengaturnya (UU No. 13 Tahun 2006). Segenap jajaran LPSK sebaiknya memiliki kemampuan inovatif dan diskresi di dalam memahami dan menafsirkan undang-undang tersebut agar kekurangan yang ada bisa diantisipasi dengan baik. Hal tersebut tentu saja niscaya adanya agar fungsi perlindungan saksi itu bisa berjalan sebagaimana mestinya. Seluruh jajaran LPSK harus terlebih dahulu memiliki pemahaman serta sikap profesionalisme yang tinggi tentang lembaga ini dan memahami hakekat diri manusia yang sejatinya tidak pernah bisa diharap untuk memperbaiki masyarakat dan lingkungannya hatta terhadap dirinya sendiri, termasuk upaya merevisi undang-undang tersebut agar lebih baik. 


\section{DAFTAR PUSTAKA}

Anthon F. Susanto. Wajah Peradilan Kita. Bandung: Refika Aditama, 2004.

Arief, Barda Nawawi. Masalah Penegakan Hukum dan Kebijakan Hukum Pidana Dalam Penanggulangan Kejahatan. Jakarta: Kencana Prenada Media Group, 2007.

Ahkam Jayadi. Memahami Tujuan Penegakan Hukum Sebuah Pendekatan Hikmah. Yogyakarta: Genta Press, 2015.

Constanzo, Mark. Aplikasi Psikologi dalam Sistem Hukum. Yogyakarta: Pustaka Pelajar, 2006.

Harkristuti Harkrisnowo. Pemerintah Harap Terapkan Alternatif Peradilan Anak, Bandung: Refika Aditama, 2003.

Nitibaskara, Ronny Rahman, Tegakkan Hukum Gunakan Hukum. Jakarta: Penerbit Buku Kompas, 2007.

Sholehuddin. Sistem Sanksi Dalam Hukum Pidana Ide Dasar Double Track System dan Implementasinya. Jakarta: PT. Raja Grafindo Persada, 2004.

Soedibroto, Soenarto. KUHP dan KUHAP Dilengkapi Yurisprudensi Mahkamah Agung dan Hoge Raad. Jakarta: PT. Raja Grafindo Persada, 2006.

Harahap, Yahya S.H. Pembahasan Permasalahan Dan Penerapan KUHAP Penyidikan dan Penuntutan, Jakarta: Sinar Grafika, 2007.

Anonim, Undang Undang Perlindungan Saksi dan Korban UU Nomor 13 Tahun 2006. Jakarta: AM Asa Mandiri, 2007.

Website Komisi Hukum Nasional (www.komnasham.go.id) artikel, Harkristuti Harkrisnowo, Kesejahteraan Perempuan di Indonesia dalam Perspektif Hukum dan Hak Asasi Manusia, 25 April 2007. 